\title{
Ensilaje liquido de residuos de durazno (Prunus pérsica) como alternativa para la alimentación animal
}

\author{
Liquid silage of peach residues (Prunus pérsica) \\ as an alternative for animal feed
}

\begin{abstract}
Gabriel Fernando Saavedra Montañez Luis Miguel Borrás Sandoval ${ }^{\text {b* }}$ Deisy Carolina Cala Guerrero ${ }^{c}$

Fecha de Recepción: 13.4.19

Fecha de Aceptación: 9.9.19

DOI: https://doi.org/10.19053/01217488.v11.n1.2020.8960

\section{Resumen}

Se evaluó la composición química y la presencia de microorganismos en ensilaje líquido de durazno (Prunus pérsica). Se utilizó un diseño completamente al azar con arreglo factorial $2 * 2$, cuatro tratamientos con dos porcentajes de inclusión de melaza y sulfato de amonio: T1 (10\% melaza - $1 \%$ SAM), T2 (10\% melaza - 3\% SAM), T3 (20\% melaza - 1\% SAM) y T4 (20\% melaza - 2\% SAM), con tres repeticiones, los cuales fueron almacenados entre 17 y $19^{\circ} \mathrm{C}$. Se determinó la composición físico-química del fruto, tomando valores de $\mathrm{pH}$ y crecimiento microbiológico, se caracterizó la morfología bacteriana en agar sangre y agar MacConkey. La evaluación organoléptica del ensilaje final se establece como BUENO según características fermentativas. El valor de proteína aumento en cada uno de los tratamientos conforme disminuía el valor de $\mathrm{pH}$, asociado a altos crecimientos microbiales mejorando la proteína verdadera del alimento. Hubo crecimiento de colonias blanquecinas y lisas en Agar sangre con predominio de formas bacilares Gram + y Gram -. En Agar MacConkey crecieron colonias de color rosado - superficie lisa solo el día 0. El ensilaje líquido de durazno con la adicción de SAM aumenta los valores de proteína; y la adición de melaza mejora los parámetros fermentativos como estabilidad del $\mathrm{pH}$.
\end{abstract}

Palabras Clave: Anaerobiosis, Conservación, Fermentación, MacConkey,

\begin{abstract}
The chemical composition and the presence of microorganisms in liquid silage of peach (Prunus pérsica) were evaluated. A completely randomized design with a $2 * 2$ factorial arrangement, four treatments with two percentages of inclusion of molasses and ammonium sulfate was used: T1 (10\% molasses - 1\% SAM), T2 (10\% molasses - 3\% SAM), T3 (20\% molasses - 1\% SAM) and T4 (20\% molasses - 2\% SAM), with three replications, which were stored between 17 and $19^{\circ} \mathrm{C}$. The physical-chemical composition of the fruit was determined, taking $\mathrm{pH}$ values and microbiological growth, bacterial morphology was characterized on blood agar and MacConkey agar. The organoleptic evaluation of the final silage is established as GOOD according to fermentation characteristics. The protein value increased in each of the treatments as the $\mathrm{pH}$ value decreased, associated with high microbial growths, improving the true protein of the food. There was growth of whitish and smooth colonies in blood agar with a predominance of Gram + and Gram - bacillary forms. Pink color - smooth surface colonies grew on MacConkey Agar only on day 0. Liquid peach silage with the addition of SAM increases protein values; and the addition of molasses improves the fermentative parameters such as $\mathrm{pH}$ stability.
\end{abstract}

Keywords: anaerobiosis, conservation, fermentation, MacConkey

a Gabriel Fernando Saavedra Montañez, Investigador, Grupo de Investigación en Bioquímica y Nutrición Animal, Facultad de ciencias Agropecuarias, Universidad Pedagógica y Tecnológica de Colombia, UPTC gafesamo@ gmail.com

b Luis Miguel Borrás Sandoval: Docente Universidad Pedagógica y Tecnológica de Colombia, UPTC. Grupo de Investigación GIBNA. Colombia. Luis.borras@uptc.edu.co

c Deisy Carolina Cala Guerrero, Grupo de Investigación en Bioquímica y Nutrición Animal, Facultad de ciencias Agropecuarias, Universidad Pedagógica y Tecnológica de Colombia. Tunja, Colombia. caladeisy@gmail.com 


\section{INTRODUCCIÓN}

La producción de frutales tropicales hace parte del renglón agrícola de Colombia, y a pesar de no ser representativo, la mayoría de los ingresos de las zonas productoras dependen de esta actividad [1] La mayoría de estos frutos presenta diversidad genética [2] y son altamente perecederos ante condiciones de alta precipitación y posterior desarrollo de microorganismos no deseables que alteran física, química y organolépticamente el producto [3]. Entre los factores que alteran esta producción están cambios climáticos [4,5], reducción de precios, estacionalidad de la producción y poco conocimiento en labores culturales al proceso de recolección, momento óptimo de cosecha y estado de madurez indicado; las perdidas pueden estar cerca del $30 \%$ de fruto en fresco ante ese tipo de situaciones adversas [6]

Debido a la problemática de altos costos de los alimentos en la producción animal, y considerando que Colombia es un país productor agropecuario y agroindustrial se deben crear estrategias que permitan el uso de los subproductos de estas industrias y no depender de materias primas importadas donde su precio depende de la variación de las divisas extranjeras, de modo tal que estos subproductos que son considerados desechos para otros puedan sustituir de modo parcial el uso de otras materias primas y constituyan una fuente importante de nutrientes logrando obtener un alimento de alta calidad que satisfaga los requerimientos nutricionales de los animales para su mantenimiento y producción. Para contribuir en la solución es necesaria la realización de investigaciones aplicadas las cuales profundicen en el tema de producción de alimentos alternativos los cuales se obtienen de forma simple, conservando inclusive resaltando el valor nutricional de los subproductos agrícolas y agroindustriales a un bajo costo obteniendo alimentos ricos en energía, proteínas vegetales y microbianas, así mismo es considerado un producto inocuo ya que el proceso de fermentación permite eliminar bacterias patógenas como E- coli, salmonella entre otras [7,8].

Entre las alternativas de suplementación animal, se encuentra la elaboración de ensilajes como proceso de conservación de materias primas para mitigar la escases de alimento y aumentar el aporte energético - proteico. Las condiciones apropiadas para el éxito de los ensilajes solidos es tener valores de materia seca superiores al 30\%; altos contenidos de carbohidratos, baja capacidad de amortiguación y bacterias homo fermentativas que mejoran la presentación del forraje; disminuir el $\mathrm{pH}$ y aumentar ácidos orgánicos de cadena corta como el ácido láctico. Se han utilizado múltiples aditivos que permiten mejorar la estabilidad del ensilaje, la gran mayoría de trabajos han realizado ensilajes de forrajes y de cereales con altos contenidos de materia seca y carbohidratos altamente fermentables, siendo pocos los trabajos en estado líquido y con un alto porcentaje de humedad, por ello el objetivo de la investigación fue determinar el valor composicional y presencia de microorganismos en ensilaje liquido de durazno (Prunus pérsica).

\section{MATERIALES Y MÉTODOS}

Localización: El estudio se llevó a cabo en los laboratorios de Nutrición y Alimentación Animal y de Fisiología vegetal de la facultad de Ciencias Agropecuarias de la Universidad Pedagógica y Tecnológica de Colombia. El fruto empleado fue durazno (Prunus pérsica) var dorado en estado de madurez avanzado y recogidos de la finca San Carlos - municipio de Tuta, Boyacá $(2600 \mathrm{msnm}$, $\mathrm{T}=14^{\circ} \mathrm{C}$ y precipitación - $1000 \mathrm{~mm}$ ). Se tomaron 5 $\mathrm{kg}$ de tamaños distintos y se empacaron en recipientes plásticos.

Diseño experimental. Se utilizó un diseño completamente al azar con arreglo bifactorial correspondiente a dos porcentajes de inclusión de sulfato de amonio (1-3\%) y dos porcentajes de melaza (10-20\%) asignados de la siguiente forma: T1 (1\% urea $-10 \%$ melaza), T2 ( $1 \%$ urea $-20 \%$ melaza), T3 (3\% urea $-10 \%$ melaza) y T4 (3\% urea $-20 \%$ melaza), cada tratamiento se repitió por triplicado, para un total de 12 Unidades experimentales (UE), cada una compuesta por 400 gr de fruto.

Preparación del ensilado: Para la elaboración de ensilaje líquido, el fruto se cortó en partículas de $2 \mathrm{~cm}$ aproximadamente, depositados en recipientes plásticos con capacidad para 2lt con adición de melaza, sulfato de amonio correspondiente al tratamiento y agua hasta cubrir la mezcla, posteriormente fueron cerrados de forma hermética asegurando un medio anaerobio y depositados en un cuarto oscuro a temperatura ambiente

\section{Caracterización fisicoquímica del fruto}

se realizó determinando variables como

- Firmeza del material vegetal $(\mathrm{N})$ por medio de penetrómetro digital PCE-PTR200 con aproximación $0,05 \mathrm{~N}$ 
- Sólidos solubles totales (SST) se determinó a través de mediciones de grados Brix con un refractómetro digital marca Hanna de rango 0 a $85 \%$ con precisión $0,1^{\circ}$ Brix

- $\quad \mathrm{pH}$ se determinó tomando $1 \mathrm{ml}$ de sustrato producto del macerado del material vegetal previamente mezclado y medido con un potenciómetro previamente calibrado con soluciones buffer de $\mathrm{pH} \mathrm{7,0}$

- Acidez titulable (ATT) se midió utilizando $1 \mathrm{ml}$ de sustrato al cual se le adiciono 3 gotas de fenoftaleína en una titulación potenciométrica hasta $\mathrm{pH}$ de 8,2

- Madurez mediante la relación SST/ATT.

Análisis químico: Se les realizó análisis químico a las muestras tomadas a diferentes tiempos. El total de los sólidos que quedó en los recipientes se secaron y se molieron en un molino de martillo marca UDY®, con criba de $1 \mathrm{~mm}$, para análisis de cuantificación.

- $\mathrm{pH}$ : El contenido de los recipientes de cada tratamiento fue recolectado en su totalidad y homogenizado, luego se tomaron $5 \mathrm{~g}$ de muestra que se colocaron en Erlenmeyer de $100 \mathrm{~mL}$ y se les adicionó $45 \mathrm{~mL}$ de agua destilada estéril. La preparación se agitó durante 30 minutos en un agitador eléctrico marca Adams ${ }^{\circledR}$ y posteriormente se obtuvo el filtrado para medición del $\mathrm{pH}$ en un potenciómetro automático marca Okaton $\AA$, Se realizaron mediciones a las 0 , 24 y 48 horas del proceso de fermentación así mismo a los días 7 y 21 del estudio.

- Materia seca (MS). El método se basa en el secado de una muestra en un horno y su determinación por diferencia de peso entre el material seco y húmedo, este procedimiento es considerado un método indirecto para la determinación de la humedad por diferencia.

- Proteína bruta (PB), se determinó por el método de Kjeldahl; el material a analizar primero se digiere en $\mathrm{H} 2 \mathrm{SO} 4$, acido que convierte el $\mathrm{N}$ en (NH4)2SO4, para la digestión se utilizó ácido sulfúrico y un catalizador de selenio. Para la destilación se empleó ácido bórico al 4\%, para la titulación se utilizó una solución de HCL, la proteína cruda se calculó por la multiplicación del nitrógeno total por el factor de 6.25. [9]
- Cenizas (Cz), se determinaron como el residuo que queda al quemar con mufla los componentes orgánicos a $550^{\circ} \mathrm{C}$ durante 5 horas, método establecidos por la AOAC (2005) [9]

- Fibra Cruda (FC), Este método se basa en la digestión ácida y alcalina de la muestra obteniéndose residuo de fibra cruda y sales que con calcinación posterior se determina la fibra cruda. Se toman 2 gr de la muestra se llevan a ebullición, se le adicionaron $25 \mathrm{ml}$ de hidróxido de sodio $(0.556 \mathrm{~N})$ durante 30 minutos, con recirculación constate de agua, se realizan lavados con agua destilada caliente; seguido de esto se adicionaron $25 \mathrm{ml}$ de ácido sulfúrico (0.6 N) y se deja en el extractor de fibra cruda durante 30 minutos, pasado este tiempo fueron colocadas en la mufla a $600^{\circ} \mathrm{C}$ por aproximadamente tres horas, la pérdida de peso debido a la incineración corresponde a la FC (AOAC 1990) [9].

Las mediciones de las anteriores variables se realizaron en los días 0,7 y 21 del proceso fermentativo.

Análisis microbiológico: En cuanto a la presencia y recuento de flora microbiana, se tomó una muestra de $10 \mathrm{ml}$ del ensilaje liquido elaborado y se realizó siembra directa e invasiva sobre Agar Sangre y Agar MacConkey, estos cultivos se depositaron dentro de la cámara para anaerobiosis junto con un sobre Gaspak EZ Anaerobe Container System para realizar control del medio y eliminar el contenido de oxígeno, posteriormente fueron llevados a la incubadora a $28^{\circ} \mathrm{c}$ por 48 horas y finalmente se realizó morfología bacteriana y coloración de Gram. Para mesófilos aerobios, enterobacterias y coliformes se usó como medio de cultivo placas petrifilm en donde se depositó $1 \mathrm{ml}$ sobre el espacio dispuesto, se llevaron a la cámara de anaerobiosis e incubaron por 48 Horas y finalmente se realizó conteo de unidades formadoras de colonia. La identificación de microorganismos se realizó en los días 0, 7, 14 y 21 del proceso experimental.

Análisis estadístico: Los datos obtenidos de la caracterización fisicoquímica del fruto en fresco fueron sometidos a estadística descriptiva. Para el análisis estadístico se aplicó la prueba de homogeneidad de Levene, la prueba de normalidad por Shapiro willk, análisis de varianza (Anova) y comparación de promedios por Tukey $(\mathrm{P} \leq 0,05)$, mediante el uso del software SAS v. 9.2 (Cary, N.C). 


\section{RESULTADOS Y DISCUSIÓN}

\section{Evaluación de las propiedades organolépticas del ensilado del fruto del durazno.}

La evaluación organoléptica del producto ensilado se realizó de acuerdo a la metodología planteada por Bello [10], como se muestra en la (Tabla 2) se consideraron las condiciones de olor, color y consistencia, la valoración se realizó a los $0 ; 10 ; 15$ días de conservado.

Tabla 2. Descriptores para la evaluación organoléptica de la calidad del ensilado de acuerdo a sus características.

\begin{tabular}{cccc}
\hline Atributo & Bueno (1) & Regular (2) & Malo (3) \\
\hline Olor & Dulce/Caramelo & Ácido Suave & Pútrido \\
\hline Color & Marrón & Grisáceo Claro & Gris Oscuro Negruzco \\
\hline Consistencia & Pastosa & Semilíquido & Líquido
\end{tabular}

Según lo anterior y evaluado el producto final el fermentado cumple con lo establecido para un ensilaje bueno, teniendo en cuenta sus características organolépticas, para todos los tratamientos en todos los tiempos de fermentación.

La buena calidad del ensilaje de residuos poscosecha de durazno, coincide de acuerdo a las características organolépticas (olor, color y consistencia), pudo deberse al aporte significativo de carbohidratos solubles, materia seca, y $\mathrm{pH}$ bajo, estos parámetros son determinantes en la fermentación de los ensilados [11].

\section{Caracterización fisicoquímica del fruto}

Tabla 1. Características físico-químicas del fruto de durazno (Prunus pérsica). Var. Dorado en estado de madurez avanzado.

\begin{tabular}{|c|c|c|c|c|c|c|c|c|c|c|}
\hline \multirow[b]{3}{*}{ Fruto } & & & & & \multicolumn{3}{|c|}{ Color } & \multirow[b]{2}{*}{ Indice } & \multirow[b]{3}{*}{ pH } & \multirow[b]{3}{*}{ RM } \\
\hline & & Firmeza & SST & & & & & & & \\
\hline & Peso (gr) & (N) & (Brix) & AT & $R$ & $G$ & $B$ & respiración & & \\
\hline U1 & 10,8 & 12,8 & 14,6 & 0,16 & 375 & 282 & 140,6 & \multirow{3}{*}{25,98} & 3,94 & 3,71 \\
\hline U2 & 98,7 & 23,73 & 15,2 & 0,16 & 308 & 220 & 97 & & 3,73 & 4,08 \\
\hline U3 & 12,9 & 30,28 & 14,2 & 0,19 & 294,6 & 253,6 & 120,33 & & 3,42 & 4,15 \\
\hline U4 & 97,9 & 29,05 & 12,5 & 0,13 & 267,6 & 210,67 & 108,6 & \multirow{3}{*}{26,61} & 3,49 & 3,58 \\
\hline U5 & 103,8 & 24,38 & 14,8 & 0,15 & 311,3 & 237 & 98,66 & & 3,86 & 3,83 \\
\hline U6 & 113,4 & 30,33 & 16 & 0,13 & 274 & 197,6 & 99,66 & & 3,66 & 4,37 \\
\hline
\end{tabular}

Son pocos los trabajos realizados en estado líquido, por consiguiente, parte de la discusión se realizó a partir de ensayos elaborados con desechos de frutas sometidas a ensilaje sólido con y sin adicción de microorganismos y/o aditivos. Las condiciones que permiten elaborar un ensilaje líquido de óptima calidad son asegurar que el medio sea completamente anaerobio que favoreció el crecimiento de bacterias acido lácticas endófitas que van a disminuir o inhibir el crecimiento de microorganismos indeseables [12].

\section{Evaluación del proceso fermentativo y valor composicional del ensilado}

El principal indicador evaluado fue el $\mathrm{pH}$ (grafica 1), se observó que el tratamiento 2 al final de la fermentación presento los valores más bajos 
$3.54(\mathrm{p}<0,05)$ sin embargo el comportamiento para todos los tratamientos fue lo esperado con un descenso progresivo hasta llegar a valores que permiten inferir una buena calidad del producto fermentado desde el punto de vista microbiológico.

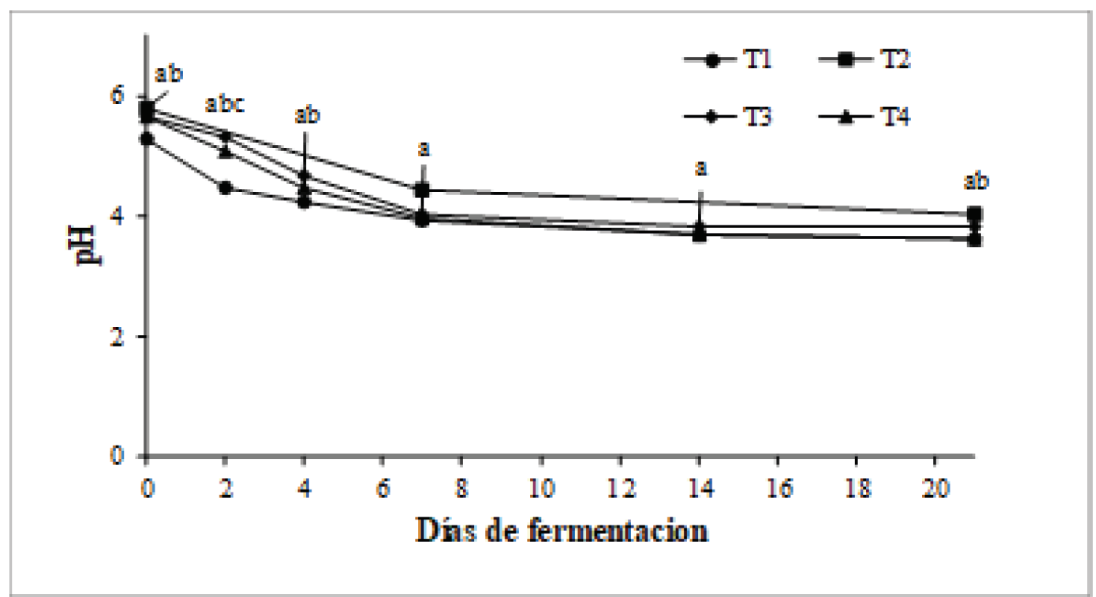

Grafica 1. Comportamiento del pH en la fermentación de los residuales poscosecha de durazno. Promedios con letras distintas indican diferencia significativa, entre dietas para cada tiempo de muestreo, según la prueba de Tukey $(\mathrm{P} \leq 0,05)$.

Valores de $\mathrm{pH}$ entre 3,8 y 4,2 son considerados adecuados para ensilajes conservados, porque en este rango hay restricción para el desarrollo de las enzimas proteolíticas de las plantas, de las enterobacterias y clostrídeos [13].

Proteina: se destacaron los tratamientos 3 y 4 con valores superiores al $11 \%$ lo cual es muy importante para la suplementación animal (grafica 2). El bajo pH obtenido en el proceso de fermentación podría inferir un crecimiento de bacterias deseables como las bacterias ácido lácticas (BAL), esta estabilidad se asocia a buenos crecimientos microbiales y por ende a buena producción de origen microbiano mejorando la proteína verdadera del alimento destacándose un significativo crecimiento de las proteínas en las fermentaciones sólidas y en especial las inoculadas con BAL. [14,15]. Asi mismo, este aumento está relacionado con el aporte de nitrógeno (urea) utilizado con los carbohidratos de fácil fermentación en la formación de protoplasma celular sin descartar una relación un incremento de la proteína por la reducción de la materia seca [16].

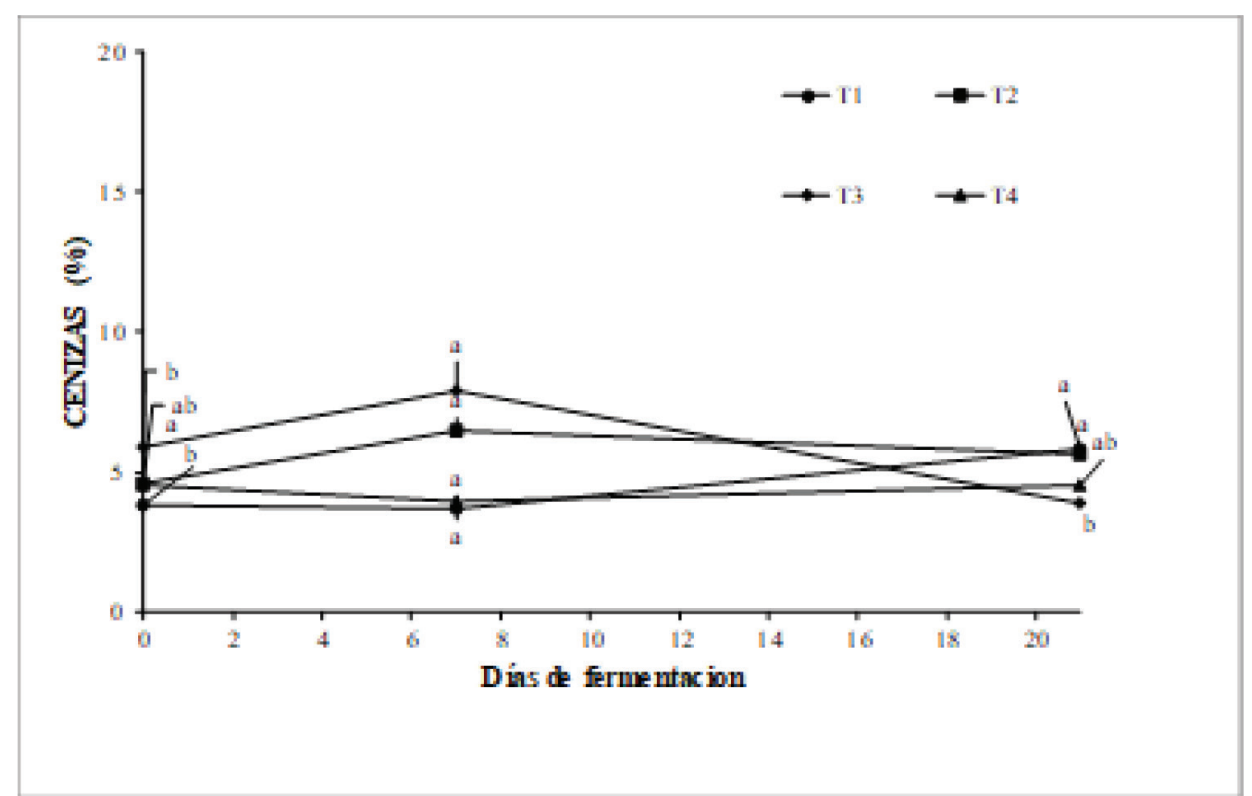

Grafica 2. Comportamiento de los indicadores de proteína en la fermentación de los residuales poscosecha de durazno. Promedios con letras distintas indican diferencia significativa, entre dietas para cada tiempo de muestreo, según la prueba de Tukey $(\mathrm{P} \leq 0,05)$ 
Cenizas: Se observó un comportamiento muy similar en la composición mineral del fermentado $(p<0,05)$, estudios realizados señalaron que los minerales son importantes para el metabolismo de la microbiota; pero en pequeñas cantidades [17] (Grafica 3).

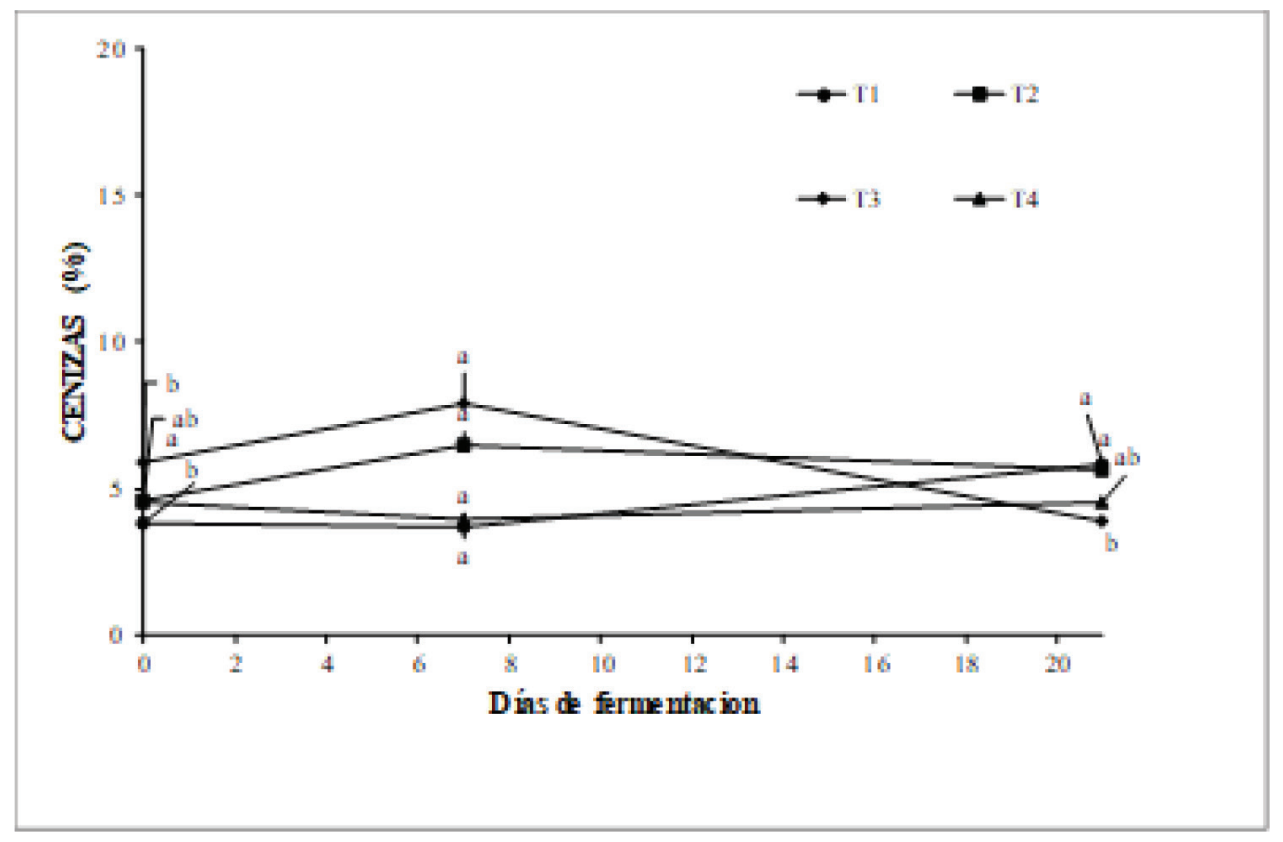

Grafica 3. Comportamiento de los indicadores de Ceniza en la fermentación del residual pos cosecha de durazno. Promedios con letras distintas indican diferencia significativa, entre dietas para cada tiempo de muestreo, según la prueba de Tukey $(\mathrm{P} \leq 0,05)$

Materia seca: se comportó según lo esperado (6 y $8 \%$ ) ya que es un fruto altamente suculento sin embargo con esta materia seca y una baja fibra hace posible la alimentación de animales especialmente monogástricos, sin embargo, en la alimentación de rumiantes se recomienda ser mezclado con una fuente mayor de fibra (Grafica 4).

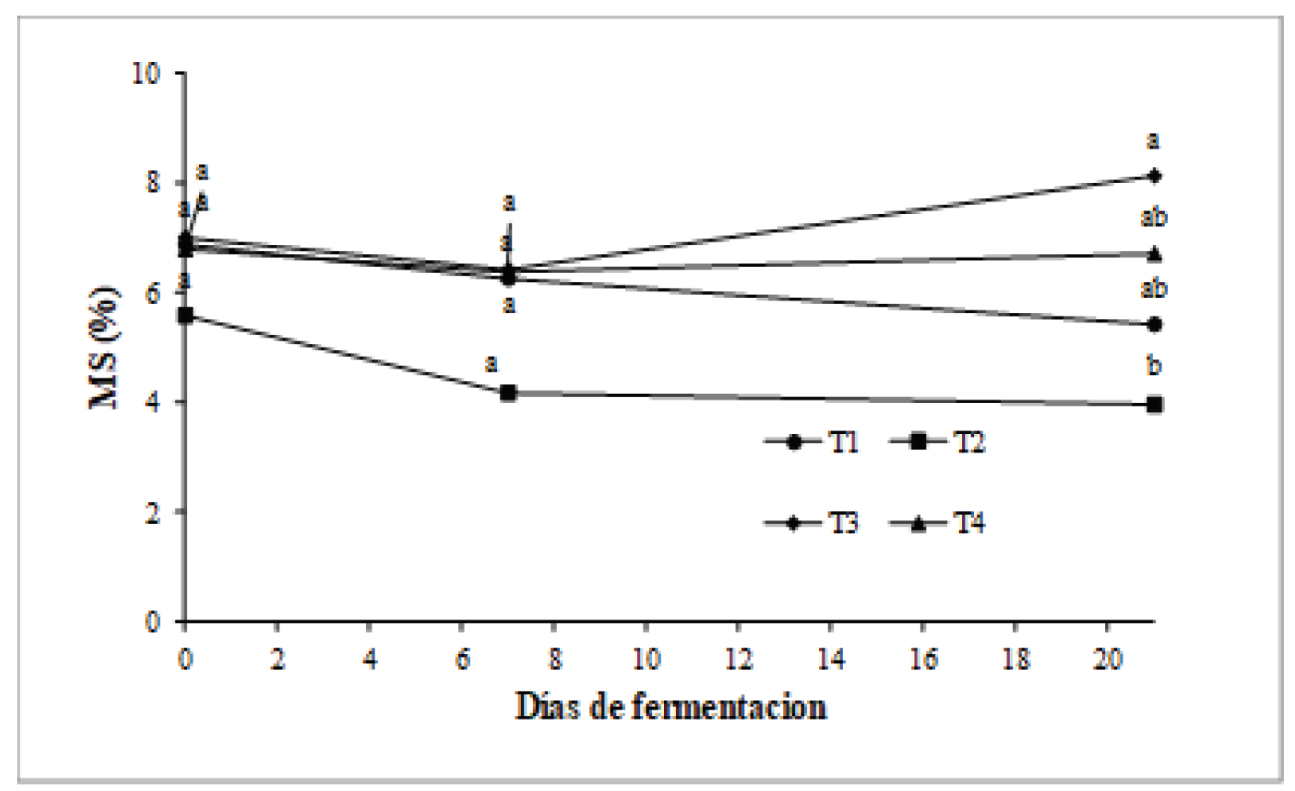

Grafica 4. Comportamiento de los indicadores de MS en la fermentación de los residuales poscosecha de durazno. Promedios con letras distintas indican diferencia significativa, entre dietas para cada tiempo de muestreo, según la prueba de Tukey $(\mathrm{P} \leq 0,05)$ 
Fibra: se encuentra un incremento en los porcentajes de esta, con diferencias significativas $(\mathrm{p}<0,05)$, que fácilmente duplica este indicador en la reportado para el fruto del durazno. El incremento de la fibra se puede deber a que el tiempo de fermentación incrementa significativamente el contenido de paredes celulares, en relación al contenido de almidón del producto usado [18] y a la fermentación de los azúcares por los microorganismos que se desarrollan en el sistema [19].

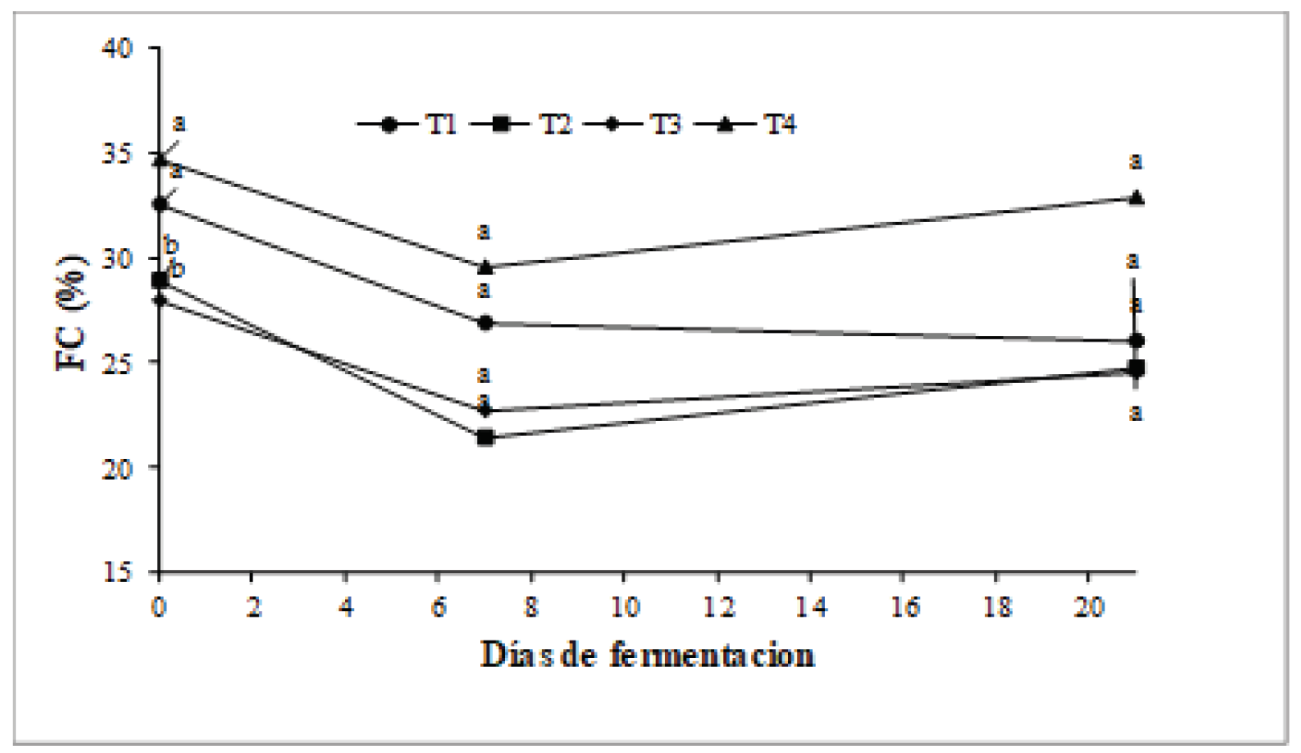

Grafica 5. Comportamiento de los indicadores de FC en la fermentación de los residuales poscosecha de durazno. Promedios con letras distintas indican diferencia significativa, entre dietas para cada tiempo de muestreo, según la prueba de Tukey $(\mathrm{P} \leq 0,05)$

\section{Análisis microbiológico}

Presencia de Microorganismos. La actividad de crecimiento microbial varió durante el periodo de fermentación, y se caracterizó por la presencia y ausencia de colonias bacterianas. La siembra realizada sobre agar Sangre y agar Macconkey en cada uno de los tratamientos tuvo variabilidad en la presencia de colonias. En agar Sangre hubo crecimiento microbial en todos los tratamientos, mientras que en agar Macconkey después del día 7 no se registró crecimiento en ninguno de los tratamientos. No hubo crecimiento de mesofilos aerobios, enterobacterias ni coliformes en placas Petrifilm al simular un ambiente de anaerobiosis. El crecimiento de levaduras presento diferencias estadísticas significativas $(\geq 0,01)$, ya que en el día 0 cero no se registró crecimiento de colonias de levaduras en ninguno de los tratamientos, el día 7 solo registro crecimiento de levaduras en el tratamiento $2(20 \%$ melaza - $1 \%$ SAM) a razón de $2.1 \times 10^{6}$. Para el día 21 se registró presencia de levaduras en el tratamiento 3 y 4 a razón de $3.4 \mathrm{x}$ $10^{6}$ y $4 \times 10^{3}$ respectivamente, como se observa en la tabla 3.

Tabla 3. Bacterias y Levaduras que crecen en ensilaje liquido de Durazno (Prunus pérsica)

\begin{tabular}{|c|c|c|c|}
\hline $\begin{array}{c}\text { TRATAMIENTO } \\
\text { DIA } 0\end{array}$ & AGAR SANGRE & AGAR MACCONKEY & LEVADURAS \\
\hline \multirow[t]{2}{*}{$\mathrm{T} 1(10 \% \mathrm{mel}-1 \% \mathrm{SAM})$} & Colonia color blanquecino y superficie lisa. & $\begin{array}{c}\text { Colonia de color } \\
\text { rosado- superficie lisa }\end{array}$ & No creció \\
\hline & $\begin{array}{l}\text { Bacilos Gram- } \\
\text { Coco Bacilos Gram }+\end{array}$ & $\begin{array}{l}\text { - lactosa positiva. } \\
\text { Bacilos Gram }+ \\
\text { Coco Bacilos Gram }+ \\
\text { Bacilos cortos Gram - }\end{array}$ & \\
\hline T2 ( $20 \% \mathrm{mel}-1 \% \mathrm{SAM})$ & $\begin{array}{l}\text { Colonia color blanquecino y superficie lisa. } \\
\text { Bacilos Gram }+ \\
\text { Cocos Gram + }\end{array}$ & $\begin{array}{l}\text { Colonia de color } \\
\text { rosado- superficie lisa } \\
\text { - lactosa positiva. } \\
\text { Coco Bacilos Gram + } \\
\text { Bacilos cortos Gram - }\end{array}$ & No creció \\
\hline
\end{tabular}




\begin{tabular}{|c|c|c|c|}
\hline T3 (10 \% mel - 3\% SAM) & No creció & $\begin{array}{l}\text { Colonia de color rosado- } \\
\text { superficie lisa - lactosa positiva. }\end{array}$ & No creció \\
\hline T4 (20\% mel - 3\% SAM) & No creció & No creció & No creció \\
\hline $\begin{array}{l}\text { TRATAMIENTO } \\
\text { DIA } 7\end{array}$ & AGAR SANGRE & AGAR MACCONKEY & LEVADURAS \\
\hline T1 (10\% mel - 1\% SAM) & $\begin{array}{l}\text { Colonia color blanquecino y superficie lisa. } \\
\text { Cocos Gram - } \\
\text { Cosos y Bacilos cortos Gram + }\end{array}$ & No creció & No creció \\
\hline T2 ( $20 \%$ mel - $1 \%$ SAM) & $\begin{array}{l}\text { Colonia color blanquecino y superficie lisa. } \\
\text { Cocos Gram }+\end{array}$ & No creció & $\begin{array}{l}2.1 \mathrm{UFC} x \\
10^{6}\end{array}$ \\
\hline T3 (10 \% mel - 3\% SAM) & $\begin{array}{l}\text { Colonia color blanquecino y superficie lisa. } \\
\text { Cocos Gram - } \\
\text { Cosos y Bacilos cortos Gram }+\end{array}$ & No creció & No creció \\
\hline T4 (20\% mel - 3\% SAM) & $\begin{array}{l}\text { Colonia color blanquecino y superficie lisa. } \\
\text { Cocos Gram - } \\
\text { Cocos y Bacilos cortos Gram }+\end{array}$ & No creció & No creció \\
\hline $\begin{array}{l}\text { TRATAMIENTO } \\
\text { DIA } 21\end{array}$ & AGAR SANGRE & AGAR MACCONKEY & LEVADURAS \\
\hline $\mathrm{T} 1(10 \% \mathrm{mel}-1 \% \mathrm{SAM})$ & $\begin{array}{l}\text { Colonia color blanquecino y superficie lisa. } \\
\text { Cocos Gram - } \\
\text { Cocos y Bacilos cortos Gram }+ \\
\text { Levaduras }\end{array}$ & No creció & No creció \\
\hline T2 ( $20 \%$ mel - $1 \%$ SAM) & $\begin{array}{l}\text { Colonia color blanquecino y superficie lisa. } \\
\text { Cocos Gram - } \\
\text { Cocos y Bacilos cortos Gram }+ \\
\text { Levaduras }\end{array}$ & No creció & No creció \\
\hline T3 (10 \% mel - 3\% SAM) & $\begin{array}{l}\text { Colonia color blanquecino y superficie lisa. } \\
\text { Cocos Gram - } \\
\text { Cocos y Bacilos cortos Gram }+ \\
\text { Levaduras }\end{array}$ & No creció & $\begin{array}{l}3.4 \text { UFC x } \\
10^{6}\end{array}$ \\
\hline T4 (20\% mel - 3\% SAM) & $\begin{array}{l}\text { Colonia color blanquecino y superficie lisa. } \\
\text { Cocos Gram - } \\
\text { Cocos y Bacilos cortos Gram }+ \\
\text { Levaduras }\end{array}$ & No creció & $4 \mathrm{UFC} \times 10^{3}$ \\
\hline
\end{tabular}

Dentro del trabajo no se realizó crecimiento específico para bacterias acido lácticas, sin embargo este tipo de bacterias crecen de forma adecuada entre los $25^{\circ}$ a $40^{\circ} \mathrm{C}$ [20] y cuentan con alta capacidad fermentadora y fortalecen el proceso de ensilaje a partir de la flora epifita más cuando favorecen temperaturas de ambientes cálidos y descenso rápido del $\mathrm{pH}$ como lo sucedido en el estudios realizados elaborando ensilajes en dos ecorregiones de Colombia [19]; donde encontró mayor crecimiento de microrganismos en ensilajes líquidos de clima cálido con respecto a los de climas frio con datos de $8.0 \mathrm{E}+10 \mathrm{Y}$ $1.5 \mathrm{E}+9$ respectivamente, posiblemente por las condiciones iniciales de temperatura que permitió un mayor crecimiento de este tipo de bacterias, coincidiendo con trabajos realizados con sacharina concluyeron que $\mathrm{pH}$ ácidos y con altas temperaturas incrementan el crecimiento bacteriano [21].

\section{CONCLUSIONES}

Los procesos de fermentación, permiten que microorganismos eficientes usen los sustratos como fuente de alimento para su multiplicación y la realización de diferentes procesos metabólicos que se generan mediante el consumo minerales, lípidos y nitrógeno en un medio favorable permitiendo el incremento en el valor de proteína cruda obtenidos partir del trabajo realizado por microorganismos principalmente bacterias acido lácticas.

El ensilaje del fruto poscosecha de durazno, presenta niveles de $\mathrm{pH}$ adecuados para garantizar la inocuidad del mismo, además presenta nutricionalmente condiciones adecuadas para ser utilizado como un suplemento alimenticio rico en energía y con niveles aceptables de proteína, fibra y materia seca que al ser suministrado con otras materias primas podría llegar a suplir parcialmente alimentos balanceados comerciales con un costo muy bajo 
frente a los mismos, para ello se recomienda realizar investigaciones con animales de diferentes especies y estados productivos suplementados con residuos de durazno fermentados para evaluar el comportamiento productivo del mismo. Al igual se sugieren realizar estudios de estabilidad, conservación y escalado del alimento obtenido por fermentación de residuos poscosecha de Durazno.

\section{REFERENCIAS}

[1] G. A. Puentes Montañéz, "Sistema de producción de frutales caducifolios en el departamento de Boyacá," Equidad y Desarro., no. 5, pp. 39-46, 2006, doi: 10.19052/ed.344.

[2] A. C. Morillo Coronado, Y. P. Tovar, and Y. Morillo, "Caracterización morfológica de Selenicereus megalanthus (K. Schum. ex Vaupel) Moran en la provincia de Lengupá," Ciencia En Desarrollo, vol. 7, no. 2, pp. 23-33, 2016. doi: 10.19053/01217488. v7.n2.2016.4072.

[3] C. H. Crisosto, E. J. Mitcham, and A. A. Kader, "Recomendaciones para mantener la calidad poscosecha," Canales Sectoriales Impresos, pp. 1-4, 2004.

[4] Y. Li et al., "Phenological response of peach to climate change exhibits a relatively dramatic trend in China, 1983-2012," Sci. Hortic. (Amsterdam)., vol. 209, pp. 192-200, 2016, doi: 10.1016/j.scienta.2016.06.019.

[5 O. Sepúlveda Delgado, Z. E. Suárez Aguilar, M. Patarroyo Mesa, S. Bautista Díaz, and L. C. Canaria Camargo, "Estudio del comportamiento e impacto de la climatología sobre el cultivo de la papa y del pasto en la región central de Boyacá empleando los sistemas dinámicos," Ciencia En Desarrollo, vol. 6, no. 2, pp. 215-224, 2015.

[6] S. Chaparro Acuña, A. Lara Sandoval, A. Sandoval Amador, S. . Sosa Suarique, J. . Martínez Zambrano, and J. Gil González, "Functional Characterization of Mango Seeds Kernel (Mangifera indica L.)," Ciencia En Desarrollo, vol. 6, no. 1, pp. 67-75, 2015, [Online]. Available: http:// www.scielo.org.co/scielo.php?script $=$ sci arttext\&pid=S0121-74882015000100009 \&lng=en\&nrm=iso\&tlng=es.
[7] D. Soler, "Importancia de los sistemas avícolas campesinos (pollo de engorde y gallina ponedora) dentro de la unidad productiva y su aporte a la seguridad alimentaria," 2010.

[8] D. Fonseca-López et al., "Caracterización nutricional y de producción de biomasa de Sambucus peruviana, Sambucus nigra y Morus alba en un banco forrajero," Ciencia en Desarrollo, vol. 10, no. 2, pp. 23-32, 2019, doi: 10.19053/01217488.v10.n2.2019.9098.

[9] R. Unido, B. Faso, and S. Leona, Centros regionales de datos de la Red internacional de datos sobre alimentos ( INFOODS ). 2015.

[10] R. Bello, E. Cardillo, and R. Martínez, "Microbial silage production from eviscerated fish," Arch. Latinoam. Nutr., vol. 43, no. 3, pp. 221-227, 1993.

[11] J. Salguero, "Evaluación de ensilaje de yuca más agua más yogurt y ensilaje de yuca y vinaza de destilería de alcohol en la alimentación de cerdos en crecimiento," 2009.

[12] T. R. Tomich, J. A. S. Rodrigues, R. G. P. Tomich, L. C. Gonçalves, and I. Borges, "Potencial forrageiro de híbridos de sorgo com capim-sudão," Arq. Bras. Med. Vet. e Zootec., vol. 56, no. 2, pp. 258-263, 2004, doi: 10.1590/s0102-09352004000200017.

[13] A. \& L. O. Elías, "Inclusión de niveles de harina de soya desgrasada y sin desgrasar en la fermentación de la caña de azúcar en estado sólido.," Rev. Cuba. Cien. Agric., p. 143, 2000.

[14] L. M. Borras Sandoval, A. E. Iglesias, and G. F. Saavedra Montañez, "Evaluación Dinámica de Conservación del producto final de un alimento obtenido por fermentación en estado Sólido de la papa (FES-papa)," Cienc. y Agric., vol. 12, no. 1, 2015.

[15] O. Brea-Maure, A. Elías-Iglesias, A. OrtizMilán, W. Motta-Ferreira, and S. Hechavarría-Riviaux, "Efecto de la urea y del tiempo en la fermentación en estado sólido de la harina de frutos del árbol del pan (Artocarpus altilis)," Cienc. Y Agric., vol. 12, no. 2, p. 91, 2015, doi: 10.19053/01228420.4395.

[16] T. Robinson, D. Singh, and P. Nigam, "Solidstate fermentation: A promising microbial technology for secondary metabolite pro- 
duction," Appl. Microbiol. Biotechnol., vol. 55, no. 3, pp. 284-289, 2001, doi: 10.1007/ s002530000565.

[17] E. Aranda, L. Georgana, J. Ramos, and S. Salgado, "Elaboración de un alimento basado en caña de azúcar a partir de la fermentación en estado sólido y con diferentes niveles de zeolitas.," Rev. Cuba. Cienc. Agric, pp. 159-163, 2012.

[18] E. Bautista, L. Mesa, and M. Gómez, "Alternatives for the production of microbial biopesticides based on fungi: the case of Latin America and the Caribbean," Sci. Agropecu., vol. 9, no. 4, pp. 585-604, 2018, doi: 10.17268/sci.agropecu.2018.04.15.
[19] A. F. Villa, A. P. Meléndez, J. E. Carulla, and M. L. Pabón, "Estudio microbiológico y calidad nutricional del ensilaje de maíz en dos ecorregiones de Colombia," Rev. Colomb. Ciencias Pecu., vol. 23, pp. 65-77, 2010.

[20] A. F., "Efecto de los niveles vitafert y melaza en la pollinaza fermentada aeróbica.," Instituto de enseñanza e investigación en ciencias agrícolas., 2010.

[21] P. L. Perdigón et al., "Yuca ensilada como fuente de energía para cerdos en crecimiento Ensiled cassava as energy source for growing pigs," Av. en Investig. Agropecu., vol. 18, no. 3, pp. 41-47, 2014. 